\title{
Modeling and Project-based learning to Improve Students Capabilities in Producing Learning Materials
}

\author{
Rahayu Pujiastuti \\ Universitas PGRI Adi Buana Surabaya \\ Surabaya, Indonesia \\ rahayu_pujiastuti@unipasby.ac.id
}

\author{
Luluk Isani Kulup \\ Universitas PGRI Adi Buana Surabaya \\ Surabaya, Indonesia \\ luluk@unipasby.ac.id
}

\begin{abstract}
This study aims to describe (1) application of modeling and project-based learning in the course of Indonesian Language and Literature Learning Planning to improve students' ability to develop learning materials; (2) improvement of student learning outcomes to compile learning materials after using modeling and project-based learning. The subjects of this study, namely 35 students of Language Education and Literature Program Indonesia. Data collection using three techniques, namely observation, questionnaires, and tests. Data analysis using percentage. The results of the research are (1) the application of modeling and project-based learning in Indonesian Language and Literature Learning Planning courses can increase student activity and student response, as evidenced by an increase from initial observation to cycle 2; (2) student learning outcomes to compile teaching materials significantly increase after using modeling and project-based learning. Students who achieve minimum completeness criteria increase from 15 students to 27 students.
\end{abstract}

Keywords—capabilities; learning materials; modeling; projectbased learning.

\section{INTRODUCTION}

In general, research that is often carried out on students of the Indonesian Language and Literature Education Study Program, Teaching and Education Faculty is a research related to the discipline of study, for example, research on writing skills [1], semantics [2], or vocabulary [3]. Rarely or has never been found research on how to improve students' ability to make learning tools, including compiling teaching materials. In fact, the results of these studies are very important because they can be used to provide appropriate attitudes related to the provision of pedagogical competencies

Ability to arrange learning materials related to pedagogic competence, namely the ability to manage to learn. These competencies include the ability to (1) understand the characteristics of learners, (2) design, implement, and assess learning, (3) apply learning theories relevant to learners and the characteristics of subjects so as to implement innovative learning.

To achieve pedagogical competence, in Curriculum Program of Language Education and Literature of Indonesia set the course of Planning of Language Learning and
Indonesian Literature. The aim is that students understand the nature, scope, and ability to apply learning materials planning to develop learning tools, including compiling learning materials.

The preparation of learning materials is one of the important materials in the course of Indonesian Language and Literature Learning Planning. For students, the material is important for long-term purposes and is able to provide supplies to the students in preparing the right materials when becoming an educator. However, also for the provision of conducting the internship course which aims for students to develop their learning and implementing microteaching in order to carry out real teaching.

Based on several previous studies in other study programs, it was stated that the ability of students' ability to learn devices was still low. This can be seen from the results of research on the ability to make assessment instruments [4], including the ability to make innovative learning media [5], the ability to make syllabi and RPP [6]

This fact also occurs in the ability of students to compile teaching materials. Based on preliminary observations obtained, information that in the material compiling teaching materials, the ability of students is still lacking. Of the 35 students, only 15 or $43 \%$ reached the minimum completeness criteria of 70 . That was because students (1) were less able to determine indicators of a basic competency, (2) lacked knowledge about how to compile teaching materials, (3) had not had the opportunity to learn innovative so that it is not able to empower its ability to think analytically and critically in compiling components of learning tools, including compiling teaching materials

The right solution for to the problem is implementing learning by modeling and project-based learning. Modeling is a contextual learning that is done by demonstrating a subject matter through a model so that students can imitateband learn to do according to the given model. Through modeling, learning is not only theoretical because students get concrete examples from various learning sources in the form of examples of learning tools in the form of learning materials.

Modeling allows combinations of innovative learning, which is project-based learning, that are product-oriented. 
Klein et al. stated that project-based learning is a learning model that uses project/activity as media. Project-based learning focuses on the activities of learners to explore, assess, interpret, synthesize, and information to produce various forms of learning outcomes [4]. Baker et al. added that project-based learning focuses on concepts and principles, in which facilitates students to solve problems, performs meaningful tasks to produce real products [5].

According to Grant, project-based learning is a learning model that centers on the learner to conduct an in-depth investigation of a topic. In this project based learning, learners do active learning through physical activity and mental/mental activities [6]. Learners can practice reasoning inductively so that their constructive conduct deepened in learning with a research-based approach to the problems and questions that are scaled, real, and relevant.

According to The George Lucas Educational Foundation, there are several project-based learning steps: (1) determining basic questions, (2) project designing, (3) preparing scheduling, (4) monitoring project progress, (5) assessment of results, and (6) evaluation of experience [7].

Based on this background, the purpose of this paper is to describe the results of the research in the form of (1) application of modeling and project-based learning in the course of PBSI Planning to improve student ability to compose learning materials and (2) improvement of student learning outcomes to arrange learning materials after using modeling and project based learning.

\section{METHOD}

The research included classroom action research. Therefore, the stages used include planning, implementation, observation and evaluation, and reflection. Subjects were 35 students in the Indonesian language and literature education study program.

Data collection was done using observation techniques, questionnaires, and performance. The data collection instrument uses observation sheets, question sheets, and product performance assessment rubrics. Analysis of observational data and questionnaire was done using percentage. Data analysis for performance (product) is done individually and then the result is the percentage.

\section{RESULT AND DISCUSSION}

Based on the research results obtained the following three information.

\section{A. Research Result}

\section{1) Cycle 1}

Each cycle uses the stages that have been determined, First, planning is done by preparing lesson plan (RPS), lecture course (SAP), learning materials, media, and instruments.

Second, the action is done in the implementation of cycle 1 of two meetings. Before the implementation, a simulation was conducted so that the students understood the learning steps.
Implementation is done in accordance with SAP that uses modeling and project-based learning.

Third, observation and evaluation are conducted. The observation results obtained student activity as follows.

TABLE I. STUDENT ACTIVITY ON CYCLE 1

\begin{tabular}{|c|c|c|c|c|c|}
\hline \multirow{2}{*}{ Activity } & \multicolumn{5}{|c|}{ Occurrences (\%) } \\
\hline & 1 & 2 & 3 & 4 & 5 \\
\hline $\begin{array}{l}\text { Responding to the } \\
\text { lecturer's explanation }\end{array}$ & $\begin{array}{c}2 \\
5,7 \% \\
\end{array}$ & $\begin{array}{c}5 \\
14,3 \% \\
\end{array}$ & $\begin{array}{c}10 \\
28,6 \% \\
\end{array}$ & $\begin{array}{c}10 \\
28,6 \% \\
\end{array}$ & $\begin{array}{c}8 \\
22,8 \% \\
\end{array}$ \\
\hline $\begin{array}{l}\text { Make an idea when } \\
\text { choosing a topic }\end{array}$ & $\begin{array}{c}3 \\
8,5 \%\end{array}$ & $\begin{array}{c}5 \\
14,3 \%\end{array}$ & $\begin{array}{c}10 \\
28,6 \%\end{array}$ & $\begin{array}{c}10 \\
28,6 \%\end{array}$ & $\begin{array}{c}7 \\
20 \%\end{array}$ \\
\hline Create project design & $\begin{array}{c}3 \\
8,5 \% \\
\end{array}$ & $\begin{array}{c}2 \\
5,7 \% \\
\end{array}$ & $\begin{array}{c}11 \\
31,2 \% \\
\end{array}$ & $\begin{array}{c}9 \\
26 \% \\
\end{array}$ & $\begin{array}{c}10 \\
28,6 \% \\
\end{array}$ \\
\hline $\begin{array}{l}\text { Arrange the schedule/ } \\
\text { stages of activity }\end{array}$ & $\begin{array}{c}2 \\
5,7 \% \\
\end{array}$ & $\begin{array}{c}5 \\
14,3 \% \\
\end{array}$ & $\begin{array}{c}10 \\
28,6 \% \\
\end{array}$ & $\begin{array}{c}10 \\
28,6 \%\end{array}$ & $\begin{array}{c}8 \\
22,8 \% \\
\end{array}$ \\
\hline $\begin{array}{l}\text { Actively follow the } \\
\text { completion of the } \\
\text { project }\end{array}$ & 0 & $\begin{array}{c}3 \\
8,5 \%\end{array}$ & $\begin{array}{c}7 \\
20 \%\end{array}$ & $\begin{array}{c}14 \\
40,3 \%\end{array}$ & $\begin{array}{c}11 \\
31,2 \%\end{array}$ \\
\hline $\begin{array}{l}\text { Actively follow the } \\
\text { creation of publica- } \\
\text { tions/final reports }\end{array}$ & $\begin{array}{c}3 \\
8,5 \%\end{array}$ & $\begin{array}{c}5 \\
14,3 \%\end{array}$ & $\begin{array}{c}10 \\
28,6 \%\end{array}$ & $\begin{array}{c}10 \\
28,6 \%\end{array}$ & $\begin{array}{c}7 \\
20 \%\end{array}$ \\
\hline $\begin{array}{l}\text { Actively participate in } \\
\text { the presentation }\end{array}$ & $\begin{array}{c}3 \\
8,5 \%\end{array}$ & $\begin{array}{c}3 \\
8,5 \%\end{array}$ & $\begin{array}{c}10 \\
28,6 \%\end{array}$ & $\begin{array}{c}11 \\
31,6 \%\end{array}$ & $\begin{array}{c}8 \\
22,8 \%\end{array}$ \\
\hline $\begin{array}{l}\text { Actively follow the } \\
\text { implementation of the } \\
\text { revision }\end{array}$ & $\begin{array}{c}1 \\
3,1 \%\end{array}$ & $\begin{array}{c}3 \\
8,5 \%\end{array}$ & $\begin{array}{c}10 \\
28,6 \%\end{array}$ & $\begin{array}{c}11 \\
31,2 \%\end{array}$ & $\begin{array}{c}10 \\
28,6 \%\end{array}$ \\
\hline & $\begin{array}{c}17 \\
6,1 \% \\
\end{array}$ & $\begin{array}{c}31 \\
11 \%\end{array}$ & $\begin{array}{c}78 \\
27,9 \% \\
\end{array}$ & $\begin{array}{c}85 \\
30,4 \% \\
\end{array}$ & $\begin{array}{c}69 \\
24,6 \% \\
\end{array}$ \\
\hline Amou & & & & $82,9 \%$ & \\
\hline
\end{tabular}

In the table, students' activity were calculated on score 3, 4 , and 5 which means enough, good, and very good. Table I shows that the liveliness of the students reached $82.9 \%$.

For student response after implementing learning with modeling and project-based learning in cycle 1 can be seen in the following results

TABLE II. STUDENT RESPONSE TO CyClE 1

\begin{tabular}{|c|c|c|c|}
\hline No & $\begin{array}{l}\text { Student Response } \\
\end{array}$ & Yes & Not \\
\hline 1. & $\begin{array}{l}\text { Learning about materials compiling learning } \\
\text { materials through modeling and project-based } \\
\text { learning is fun }\end{array}$ & $\begin{array}{c}31 \\
88,6 \%\end{array}$ & $\begin{array}{c}4 \\
11,4 \%\end{array}$ \\
\hline 2. & $\begin{array}{l}\text { Learning on materials composing learning } \\
\text { materials through modeling and project-based } \\
\text { learning is helpful in understanding the } \\
\text { concept }\end{array}$ & $\begin{array}{c}27 \\
77,1 \%\end{array}$ & $\begin{array}{c}8 \\
22,9 \%\end{array}$ \\
\hline 3. & $\begin{array}{l}\text { Learning about materials composing learning } \\
\text { materials through modeling and project-based } \\
\text { learning helps to understand the elements for } \\
\text { compiling learning materials }\end{array}$ & $\begin{array}{c}27 \\
77,1 \%\end{array}$ & $\begin{array}{c}8 \\
22,9 \%\end{array}$ \\
\hline 4. & $\begin{array}{l}\text { Learning on the material composing the lear- } \\
\text { ning materials through modeling and project- } \\
\text { based learning facilitates critical thinking }\end{array}$ & $\begin{array}{c}21 \\
60 \%\end{array}$ & $\begin{array}{c}14 \\
40 \%\end{array}$ \\
\hline \multirow[t]{2}{*}{5} & $\begin{array}{l}\text { Learning on the materials of learning materials } \\
\text { through modeling and project-based learning } \\
\text { adds courage/confidence when conveying a } \\
\text { concept }\end{array}$ & $\begin{array}{c}25 \\
71,4 \%\end{array}$ & $\begin{array}{c}10 \\
28,6 \%\end{array}$ \\
\hline & & $\begin{array}{c}131 \\
74,9 \%\end{array}$ & $\begin{array}{c}44 \\
25,1 \%\end{array}$ \\
\hline
\end{tabular}


Unlike student activeness, student responses are calculated based on Yes or No answers. Based on table II, students' activity reached $74.9 \%$.

TABLE III. STUdents CAPABILITIES PRoducing LeARning Materials IN CYCLE 1

\begin{tabular}{|c|c|c|c|}
\hline $\begin{array}{c}\text { Percentage level of } \\
\text { mastery interval }\end{array}$ & $\begin{array}{c}\text { Criteria of Learning } \\
\text { Achievement }\end{array}$ & Frequency & Percentage \\
\hline $86-100$ & Very Good & 0 & 0 \\
\hline $70-85$ & Good & 23 & 65,7 \\
\hline $60-69$ & Enough & 9 & 25,7 \\
\hline $41-59$ & Less & 3 & 8,6 \\
\hline $0-40$ & Very Less & 0 & 0 \\
\hline \multicolumn{2}{|r}{ Amount } & $\mathbf{3 5}$ & $\mathbf{1 0 0}$ \\
\hline
\end{tabular}

Description of aspect assessed

a) Indicators in accordance with basic competencies

b) Learning materials according to indicators

c) The teaching material considers the adequacy aspect

d) The learning materials interest students

e) Learning materials using language appropriate to students

f) Learning materials are arranged with appropriate systematics

Fourth, after the results were obtained, the next step was reflection. Based on the observation of student activity, it turns out that the students enthusiastically follow the learning especially when responding to the lecturer's explanation and make the report/product to be presented. Students who were usually silent during the lecture were already active, although there were still not actively involved. It appeared in two activities, namely completing the project and revising the product after getting advice.

Students' responses to the learning that was have impacts on the learning outcomes. If the initial observation of the ability to arrange the learning materials is still $43 \%$, in cycle 1 the ability is increased to $65.7 \%$. This is shown in table III.

Based on the results of reflection, modeling and projectbased learning can improve the ability of students to arrange learning materials. However, in cycle 1 there were still shortcomings so that the results achieved had not been maximized. Therefore, cycle 2 was done to further improve students' ability

\section{2) Cycle 2}

The planned action was basically done by using the basis of the results of reflection on cycle 1 . Strength or excess in cycle 1 were maintained, while the weaknesses in cycle 1 were improved.

Similar with cycle 1 , cycle 2 also used the stages that had been pre-determined. First, planning was done by preparing RPS, SAP, learning materials, media, and instruments.

Second, the action was done in the implementation of cycle 2 as much as two meetings. Implementation was done in accordance with SAP using modeling and project based learning.

Third, observation and evaluation were conducted. Based on the observation, the results obtained are as follows.
TABLE IV. STUDENT ACTIVITY ON CYCLE 2

\begin{tabular}{|c|c|c|c|c|c|}
\hline \multirow{2}{*}{ Activity } & \multicolumn{5}{|c|}{ Occurrences (\%) } \\
\hline & 1 & 2 & 3 & 4 & 5 \\
\hline $\begin{array}{l}\text { Responding to the } \\
\text { lecturer's explanation }\end{array}$ & 0 & 0 & $\begin{array}{c}12 \\
34,2 \%\end{array}$ & $\begin{array}{c}13 \\
37,2 \%\end{array}$ & $\begin{array}{c}10 \\
28,6 \%\end{array}$ \\
\hline $\begin{array}{l}\text { Make an idea when } \\
\text { choosing a topic }\end{array}$ & 0 & $\begin{array}{c}5 \\
14,4 \%\end{array}$ & $\begin{array}{c}10 \\
28,6 \%\end{array}$ & $\begin{array}{c}10 \\
28,6 \%\end{array}$ & $\begin{array}{c}10 \\
28,6 \%\end{array}$ \\
\hline Create project design & 0 & $\begin{array}{c}2 \\
5,7 \%\end{array}$ & $\begin{array}{c}11 \\
31,5 \%\end{array}$ & $\begin{array}{c}12 \\
34,2 \%\end{array}$ & $\begin{array}{c}10 \\
28,6 \%\end{array}$ \\
\hline $\begin{array}{l}\text { Arrange the schedule / } \\
\text { stages of activity }\end{array}$ & 0 & $\begin{array}{c}3 \\
8,5 \%\end{array}$ & $\begin{array}{c}7 \\
20 \%\end{array}$ & $\begin{array}{c}14 \\
40,3 \%\end{array}$ & $\begin{array}{c}11 \\
31,2 \%\end{array}$ \\
\hline $\begin{array}{l}\text { Actively follow the } \\
\text { completion of the } \\
\text { project }\end{array}$ & 0 & $\begin{array}{c}3 \\
8,5 \%\end{array}$ & $\begin{array}{c}7 \\
20 \%\end{array}$ & $\begin{array}{c}14 \\
40,3 \%\end{array}$ & $\begin{array}{c}11 \\
31,2 \%\end{array}$ \\
\hline $\begin{array}{l}\text { Actively follow the } \\
\text { creation of publica- } \\
\text { tions / final reports }\end{array}$ & 0 & $\begin{array}{c}5 \\
14,3 \%\end{array}$ & $\begin{array}{c}13 \\
37,2 \%\end{array}$ & $\begin{array}{c}10 \\
28,6 \%\end{array}$ & $\begin{array}{c}7 \\
19,8 \%\end{array}$ \\
\hline $\begin{array}{l}\text { Actively participate in } \\
\text { the presentation }\end{array}$ & 0 & $\begin{array}{c}2 \\
5,7 \%\end{array}$ & $\begin{array}{c}11 \\
31,5 \%\end{array}$ & $\begin{array}{c}12 \\
34,2 \%\end{array}$ & $\begin{array}{c}10 \\
28,6 \%\end{array}$ \\
\hline $\begin{array}{l}\text { Actively follow the } \\
\text { implementation of the } \\
\text { revision }\end{array}$ & 0 & $\begin{array}{c}5 \\
14,3 \%\end{array}$ & $\begin{array}{c}13 \\
37,2 \%\end{array}$ & $\begin{array}{c}10 \\
28,6 \%\end{array}$ & $\begin{array}{c}7 \\
19,8 \%\end{array}$ \\
\hline & $\mathbf{0}$ & $\begin{array}{c}25 \\
8.8 \%\end{array}$ & $\begin{array}{c}\mathbf{8 4} \\
\mathbf{3 0 \%}\end{array}$ & $\begin{array}{l}95 \\
33,8 \%\end{array}$ & $\begin{array}{c}76 \\
27,4 \%\end{array}$ \\
\hline Amou & & & & $91,2 \%$ & \\
\hline
\end{tabular}

Based on table IV, the liveliness of the students reached $82.9 \%$. That means an increase of $8.3 \%$ from cycle 1 .

For student response, after implementing learning with modeling and project-based learning in cycle 2 following results were obtained.

TABLE V. STUdENT RESPONSE TO CyCle 2

\begin{tabular}{|c|c|c|c|}
\hline No & Student Response & Yes & Not \\
\hline 1. & $\begin{array}{l}\text { Learning about materials compiling learning } \\
\text { materials through modeling and project- } \\
\text { based learning is fun }\end{array}$ & $\begin{array}{c}32 \\
91,4 \%\end{array}$ & $\begin{array}{c}3 \\
8,6 \%\end{array}$ \\
\hline 2. & $\begin{array}{l}\text { Learning on materials composing learning } \\
\text { materials through modeling and project- } \\
\text { based learning is helpful in understanding } \\
\text { the concept }\end{array}$ & $\begin{array}{c}32 \\
91,4 \%\end{array}$ & $\begin{array}{c}3 \\
8,6 \%\end{array}$ \\
\hline 3. & $\begin{array}{l}\text { Learning about materials composing } \\
\text { learning materials through modeling and } \\
\text { project-based learning helps to understand } \\
\text { the elements for compiling learning } \\
\text { materials }\end{array}$ & $\begin{array}{c}27 \\
77,1 \%\end{array}$ & $\begin{array}{c}8 \\
22,9 \%\end{array}$ \\
\hline 4. & $\begin{array}{l}\text { Learning on the material composing the } \\
\text { learning materials through modeling and } \\
\text { project-based learning facilitates critical } \\
\text { thinking }\end{array}$ & $\begin{array}{c}30 \\
86 \%\end{array}$ & $\begin{array}{c}5 \\
14 \%\end{array}$ \\
\hline 5 & $\begin{array}{l}\text { Learning on the materials of learning } \\
\text { materials through modeling and project- } \\
\text { based learning adds courage/confidence } \\
\text { when conveying a concept }\end{array}$ & $\begin{array}{c}25 \\
71,4 \%\end{array}$ & $\begin{array}{c}10 \\
28,6 \%\end{array}$ \\
\hline & Amount & $\begin{array}{c}146 \\
83,4 \%\end{array}$ & $\begin{array}{c}29 \\
16,6 \%\end{array}$ \\
\hline
\end{tabular}

Students' responses aweer calculated based on Yes or No answers. Based on table V, students' activities reaches $83.4 \%$. This means an $8.5 \%$ more that the result in cycle 1 . 
TABLE VI. Students CAPABILITIEs Producing LeARning Materials IN CYCLE 2

\begin{tabular}{|c|c|c|c|}
\hline $\begin{array}{c}\text { Percentage level of } \\
\text { mastery interval }\end{array}$ & $\begin{array}{c}\text { Criteria of Learning } \\
\text { Achievement }\end{array}$ & Frequency & Percentage \\
\hline $86-100$ & Very Good & 2 & 5,7 \\
\hline $70-85$ & Good & 25 & 71,4 \\
\hline $60-69$ & Enough & 7 & 20 \\
\hline $41-59$ & Less & 1 & 2,9 \\
\hline $0-40$ & Very Less & 0 & 0 \\
\hline \multicolumn{4}{|c|}{ Amount } \\
\hline
\end{tabular}

Description of aspect assessed

a) Indicators in accordance with basic competencies

b) Learning materials according to indicators

c) The teaching material considers the adequacy aspect

d) The learning materials interest students

e) Learning materials using language appropriate to students

f) Learning materials are arranged with appropriate systematics

Fourth, after the results were obtained, the next step that was done was reflection. Based on observations done on students' activities, there result increased. The students remain enthusiastic about learning. In this 2 nd cycle, the activity of the students no longer got the score 1 .

Students' responses to the learning were also increasing, thus affecting the learning outcomes obtained. Ability to arrange learning materials that was still $65.7 \%$, in cycle 1 increased to $77.1 \%$.

The results of reflection proved that modeling and projectbased learning can improve the ability of students to arrange learning materials, both from application and learning outcomes.

\section{B. Discussion}

Based on the data obtained in cycle 1 and cycle 2 can be explained the following three things.

\section{1) Student Activities}

In cycle 1 , student activity was still $82,9 \%$. This happened because there were still many students who had not done well. There were still $17.1 \%$ of students who had not been actively involved in the learning process starting from responding to the lecturers' explanation to actively following the implementation of the revision. This decreased in cycle 2 , in which the percentage of students' activeness increased as much as $8.3 \%$ to $91.2 \%$. Here is a graph showing the increase of cycle 1 to cycle 2 .

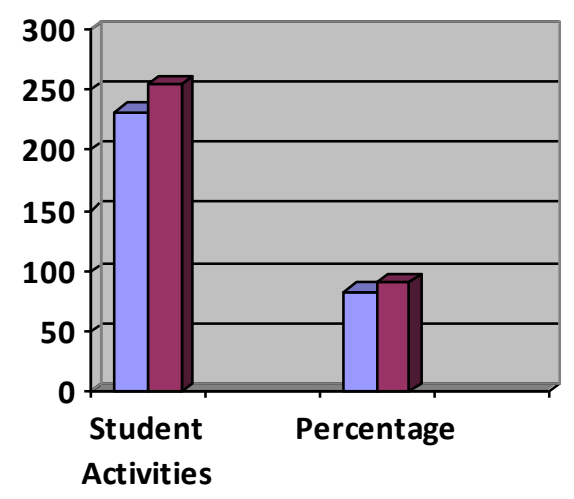

\section{2) Student Responses}

In cycle 1 , the student's response was still $74.9 \%$. There were still $25.1 \%$ of students who had not responded well. This occurred in all response indicators. When the cycle 2 occurred, the percentage of students' response increased as much as $8.5 \%$, making the students' response percentage to $83.4 \%$. Here is a graph showing the increase of cycle 1 to cycle 2

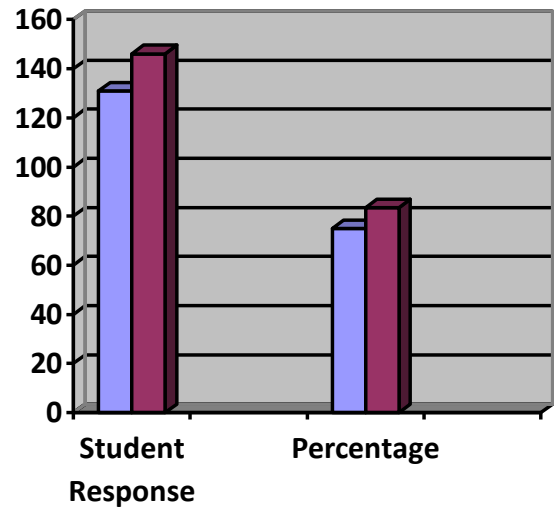

\section{3) Students Capabilities Producing Learning Materials}

In the first cycle, the amount of students who reached the minimum score were 23 people or still $65.7 \%$. The situation increased in cycle 2 to 27 students or $77.1 \%$ resulting in an increase in the percentage of students' completeness or the ability to compose the materials as much as $11.4 \%$. Here is a graph showing the increase of cycle 1 to cycle 2 . 


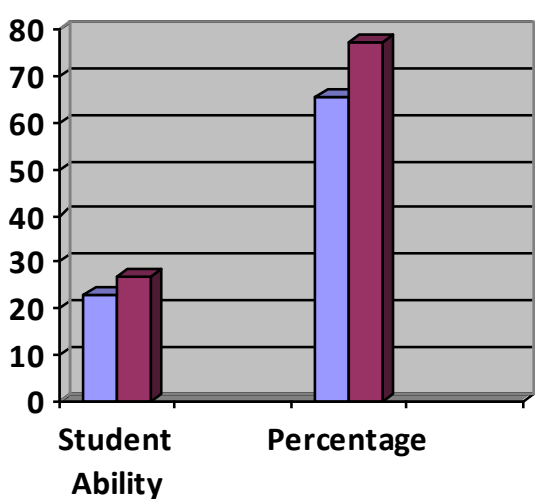

\section{CONCLUSION}

Based on the results of the study it can be concluded that (1) the application of modeling and project-based learning in Indonesian Language and Literature Learning Planning courses can increase student activity and student response, as evidenced by an increase from initial observation to cycle 2; (2) student learning outcomes to compile teaching materials significantly increase after using modeling and project-based learning. Students who achieve minimum completeness criteria increase from 15 students to 27 students.

\section{ACKNOWLEDGMENT}

The researchers would like to thank the Head of Indonesian Language and Literature Studies Program, the Dean of the Faculty of Teacher Training and Education, and the Rector of PGRI University Adi Buana Surabaya who always gave moral and material support to the progress of the lecturers.

\section{REFERENCES}

[1] V. Janusheva. "The use of the colon in the students' written expression in the Republic of Macedonia" J International Journal of Education Teacher, vol. 14, (1) 5-13, 2017.

[2] A.Rofii. "Model of contextual-based semantics learning materials (Research and development at Indonesian language and literature education department, faculty of teachers training and education Batanghari University Jambi)", in Proceedings Sixth International Conference on Languages and Arts (ICLA) Advances in Social Science, Education, and Humanities Research (ASSER), vol. 148, 2017

[3] K. Kusno and J. Purwanto. "Effectiveness of quantum learning for teaching the linear program at the Muhammadiyah Senior High School of Purwokerto in Central Jawa, Indonesia.” J. Educare, vol 4, 2011.

[4] B. Akbar and N.Y. Rustaman. :"Kemampuan mahasiswa PGSD dalam keterampilan proses sains dan pengembangan instrumen penilaian ". $J$ Evaluasi Pendidikan, vol. 2, (1) 27-39, 2011

[5] R. Novalita. "Pengaruh perencanaan pembelajaran terhadap pelaksanaan pembelajaran (Suatu penelitian terhadap mahasiswa PPLK program studi pendidikan Geografi FKIP Universitas Almuslim)". J. Lentera, vol. 14, (2) 56-61, 2014.

[6] W.S. Utami. "Pengembangan bahan ajar mata kuliah perencanaan pengajaran Geografi berbasis e-learning untuk meningkatkan hasil belajar mahasiswa". J. Geografi, vol. 11, (21) 36-50, 2013.
[7] E. Baker, B. Trygg, P.M. Tudor, and L.Ferguson. Project-based Learning Model, Relevant Learning for the 21st Century.Washington: Pacific Education Institute. 2011.

[8] J.I. Klein, S. Taveras, S.H. King, A. Commitante, L.C. Bey. ProjectBased Learning: Inspiring Middle School Student to Engage in Deep and Active Learning. New York: NYC Departement of Education. 2009

[9] M.M. Grant. "Getting a grip of project based learning: theory, cases and recommendation." J. Meridian A Middle School Computer Technologies, vol 5. 2002

[10] The George Lucas Educational Foundation. Instructional Module Project Based Learning. (Http//www.edutopia.org.modules/PBL/ whatpbl.php). Oktober, 2007. 